\title{
Teaching NeuroImages: Neurocysticercosis With Unilateral Vision Loss
}

Ramanuj Samanta, MS, Sreeram Jayaraj, MBBS, Shalaka Ramesh Waghamare, MBBS,

Athul S. Puthalath, MBBS, and Niraj Kumar, MD, DM

Neurology ${ }^{\circledR}$ 2021;96:e2035-e2036. doi:10.1212/WNL.0000000000011319

Figure Ocular and Brain MRI Images
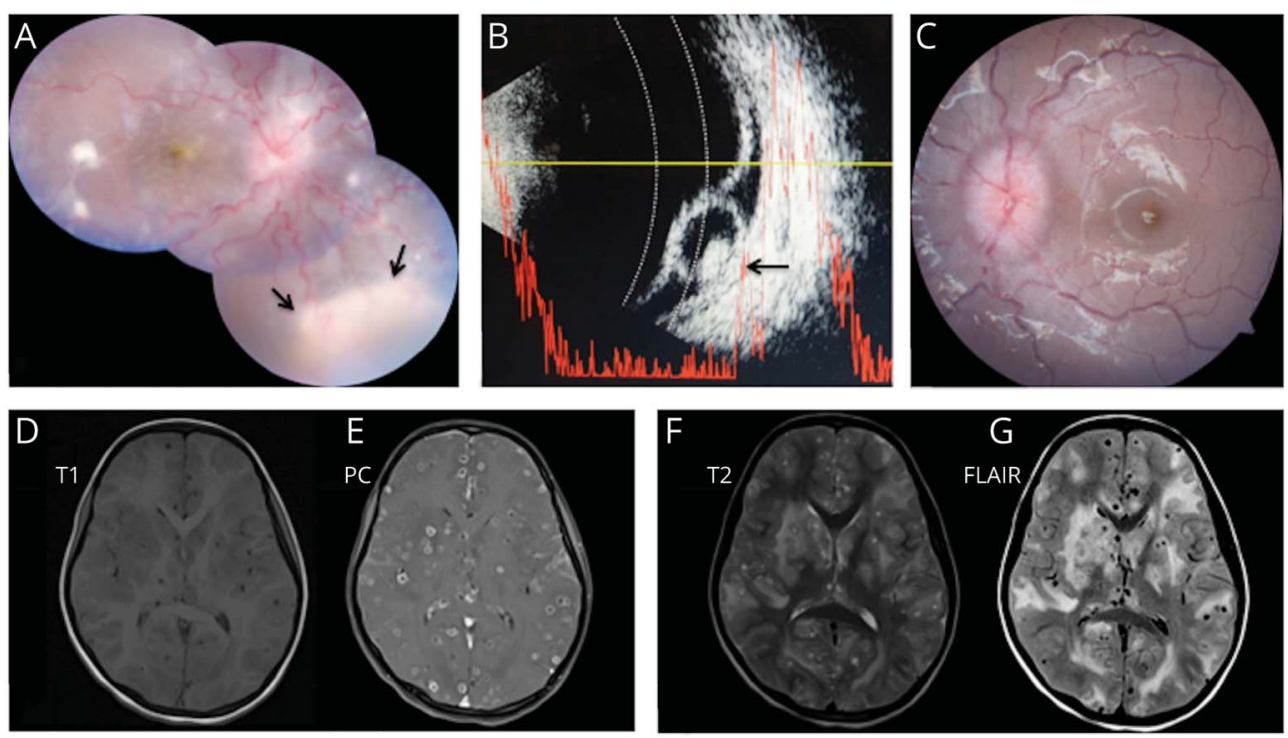

(A) Fundus photograph of right eye shows disc edema, vascular tortuosity, vitritis, neurosensory detachment, and whitish subretinal lesion inferonasally (arrows). (B) Ocular ultrasound of right eye shows hyporefractive lesion with internal hyperreflectivity (scolex; black arrow) suggestive of subretinal cysticercosis. (C) The left eye shows disc edema with normal posterior pole. Brain MRI shows multiple parenchymal neurocysticercosis in various stages on T1weighted (D) and T2-weighted (F) images, gadolinium enhancement of multiple cyst walls (E), and significant pericystic edema on fluid-attenuated inversion recovery (FLAIR) sequence $(G)$.

A 10-year-old girl presented with right eye diminished vision for 6 months along with headache and intermittent vomiting for 3 weeks. Right eye examination (figure, A) revealed light perception vision, panuveitis, and an inferonasal whitish subretinal lesion confirmed as subretinal cysticercosis (SC) on ocular ultrasound (figure, B). The left eye (figure, C) was unremarkable except for disc edema. Brain MRI findings (figure, $D-G$ ) along with clinical features of intracranial hypertension including headache and vomiting suggested multiple neurocysticercosis (MNCC). ${ }^{1}$ Oral steroids improved headache and vomiting, but not vision. Although surgical removal of SC was advised, the child's caregivers declined consent. Unilateral vision loss with panuveitis in MNCC may result from concurrent SC. ${ }^{2}$

\section{Study Funding}

No targeted funding reported.

\section{Disclosure}

The authors report no disclosures relevant to the manuscript. Go to Neurology.org/ $\mathrm{N}$ for full disclosures.

\section{Correspondence}

Dr. Kumar

drnirajkumarsingh@

gmail.com

\section{MORE ONLINE}

$\rightarrow$ Teaching slides

links.lww.com/WNL/ B296

From the Departments of Ophthalmology (R.S., S.J., S.R.W., A.S.P.) and Neurology (N.K.), All India Institute of Medical Sciences, Rishikesh.

Go to Neurology.org/N for full disclosures. 
Appendix Authors

\begin{tabular}{lll}
\hline Name & Location & Contribution \\
\hline $\begin{array}{l}\text { Ramanuj Samanta, } \\
\text { MS }\end{array}$ & $\begin{array}{l}\text { All India Institute of } \\
\text { Medical Sciences, } \\
\text { Rishikesh }\end{array}$ & $\begin{array}{l}\text { Conception, design, writing } \\
\text { the first manuscript, } \\
\text { review and critique }\end{array}$ \\
\hline $\begin{array}{l}\text { Sreeram Jayaraj, } \\
\text { MBBS }\end{array}$ & $\begin{array}{l}\text { All India Institute of } \\
\text { Medical Sciences, } \\
\text { Rishikesh }\end{array}$ & $\begin{array}{l}\text { Writing the first } \\
\text { manuscript }\end{array}$ \\
\hline $\begin{array}{l}\text { Shalaka Ramesh } \\
\text { Waghamare, MBBS }\end{array}$ & $\begin{array}{l}\text { All India Institute of } \\
\text { Medical Sciences, }\end{array}$ & $\begin{array}{l}\text { Drafting the manuscript, } \\
\text { review }\end{array}$ \\
\hline $\begin{array}{l}\text { Rishikesh } \\
\text { Athul S. Puthalath, } \\
\text { MBBS }\end{array}$ & $\begin{array}{l}\text { All India Institute of } \\
\text { Medical Sciences, }\end{array}$ & Review and critique \\
& Rishikesh & \\
\hline
\end{tabular}

Appendix (continued)

\begin{tabular}{lll}
\hline Name & Location & Contribution \\
\hline $\begin{array}{l}\text { Niraj Kumar, MD, } \\
\text { DM }\end{array}$ & $\begin{array}{l}\text { All India Institute } \\
\text { of Medical } \\
\text { Sciences, } \\
\text { Rishikesh }\end{array}$ & $\begin{array}{l}\text { Conception, design, } \\
\text { review and critique }\end{array}$ \\
& \\
\hline
\end{tabular}

\section{References}

1. Del Brutto $\mathrm{OH}$, Nash TE, White AC Jr, et al. Revised diagnostic criteria for neurocysticercosis. J Neurol Sci 2017;372:202-210.

2. Ganesh SK, Priyanka. Analysis of clinical profile, investigation, and management of. ocular cysticercosis seen at a tertiary referral centre. Ocul Immunol Inflamm 2018;26: $550-557$. 


\section{Neurology}

Teaching NeuroImages: Neurocysticercosis With Unilateral Vision Loss

Ramanuj Samanta, Sreeram Jayaraj, Shalaka Ramesh Waghamare, et al. Neurology 2021;96;e2035-e2036 Published Online before print December 4, 2020

DOI 10.1212/WNL.0000000000011319

This information is current as of December 4, 2020

\section{Updated Information \&} Services

References

Permissions \& Licensing

Reprints including high resolution figures, can be found at: http://n.neurology.org/content/96/15/e2035.full

This article cites 2 articles, 0 of which you can access for free at: http://n.neurology.org/content/96/15/e2035.full\#ref-list-1

Information about reproducing this article in parts (figures,tables) or in its entirety can be found online at:

http://www.neurology.org/about/about_the_journal\#permissions

Information about ordering reprints can be found online:

http://n.neurology.org/subscribers/advertise

Neurology ${ }^{\circledR}$ is the official journal of the American Academy of Neurology. Published continuously since 1951, it is now a weekly with 48 issues per year. Copyright @ 2020 American Academy of Neurology. All rights reserved. Print ISSN: 0028-3878. Online ISSN: 1526-632X.

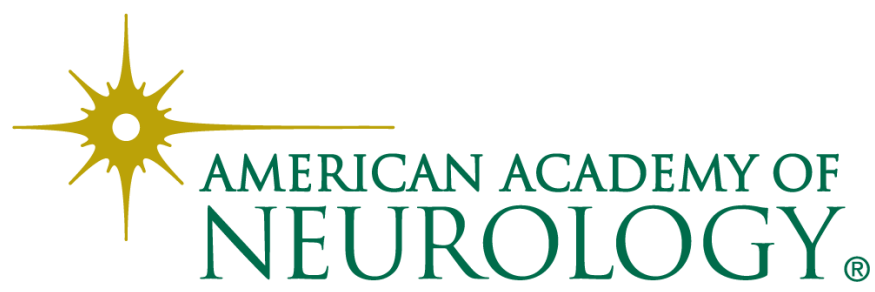

